\title{
Two-component polymer films of palladium and fullerene with covalently linked crown ether voids: effect of cation binding on the redox behavior
}

\author{
Monika Wysocka-Żołopa • Krzysztof Winkler • \\ Suresh Gadde • Francis D'Souza
}

Received: 6 October 2010 /Revised: 6 December 2010 /Accepted: 8 December 2010/Published online: 30 December 2010

(C) The Author(s) 2010. This article is published with open access at Springerlink.com

\begin{abstract}
Redox active films have been generated via electrochemical reduction in a solution containing palladium(II) acetate and fulleropyrrolidine with covalently linked crown ethers, viz., benzo-15-crown-5 and benzo-18-crown-6. In these films, fullerene moieties are covalently bonded to palladium atoms to form a polymeric network. Films show ability to coordinate alkali metal cations from the solution. Therefore, in solutions containing salts of alkali metal cations, benzo15-crown-5- $\mathrm{C}_{60} / \mathrm{Pd}$ and benzo-18-crown-6- $\mathrm{C}_{60} / \mathrm{Pd}$ films are doped with cations coordinated by crown ether moiety and anions of supporting electrolyte which enter the film to balance positive charge. These films are electrochemically active in the negative potential range due to the reduction of the fullerene moiety. Reduction of the polymer is accompanied by the transport of supporting electrolyte ions between solution and solid phase. In solution containing alkali metal salts, the process of film reduction is accompanied by the transport of anions from the film to the solution. In the presence of tetra(alkyl) ammonium salts, transport of cations from the solution to the film takes place during the polymer reduction.
\end{abstract}

\footnotetext{
M. Wysocka-Żołopa $\cdot$ K. Winkler $(\bowtie)$

Institute of Chemistry, University of Bialystok,

Hurtowa 1,

15-399, Bialystok, Poland

e-mail: winkler@uwb.edu.pl

S. Gadde $\cdot$ F. D'Souza $(\bowtie)$

Department of Chemistry, Wichita State University,

1845 Fairmount,

Wichita, KS 67260-0051, USA

e-mail: Francis.DSouza@wichita.edu
}

Keywords Redox active fullerene polymers · Crown ethers · Electropolymerization · Cation binding · Quartz crystal microbalance

\section{Introduction}

Study of fullerene derivatives has rapidly grown in recent years due to their practical applications covering diverse applications. Several synthetic approaches have been developed to prepare a variety of fullerene derivatives. For example, a series of fulleropyrrolidine derivatives were synthesized by 1,3-dipolar cycloaddition to $\mathrm{C}_{60}$ [1-10]. This procedure has been used to link a crown ether moiety to fulleropyrrolidine [11-21]. It was shown [11-14, 21] that crown ether-bearing fulleropyrrolidine possesses interesting electrochemical and photophysical properties.

Crown ethers exhibit ability to complex cations of alkali and alkali earth metals [22-24]. Hence, they have been widely used in the construction of alkali metal detectors. Recently, conjugated conducting polymers functionalized with crown ether substituents have been used as new materials for alkali metal ion detection [25-30]. These materials can be used for fabrication of all-solid sensing electrodes [31].

Recently, we developed an electrochemical procedure for the formation of two-component fullerene films based on the electroreduction carried out in a solution containing fullerene [32-36] or fullerene derivatives [37-40] and various transition metal complexes. In these polymers, fullerene moieties are covalently bonded to transition metal atoms or their complexes to form a polymeric network. These materials exhibit electrochemical activity in the negative potential range due to rich electroreduction of the fullerene moieties. Films containing fullerene derivatives 
with covalently attached redox probe, ferrocene, zinc porphyrin, or single-wall carbon nanotubes additionally show electrochemical activity at positive potentials [3739]. In this case, the oxidation of electron-donating redox groups attached to the main backbone of the polymer is responsible for the anodic redox activity.

The process of reduction or oxidation of polymeric fullerene-based materials is accompanied by the transport of charge-compensating counterions within the matrix [33, 37]. The overall control of charge percolation through the electroactive material is governed by the transport of these counter ions. It was found that different factors can influence the rate of ion transport through the polymeric layer. The degree of solvent swelling [41-43], size of supporting electrolyte ions [33], and morphology of the polymeric material [44] are the most important factors that determine the redox properties of the layer.

In this paper, we examine the formation of new polymeric films prepared by reduction in solution containing palladium(II) acetate and fulleropyrrolidine with covalently linked crown ethers, benzo-15-crown-5- $\mathrm{C}_{60}$ and benzo-18-crown-6- $\mathrm{C}_{60}$ (Scheme 1). Electrochemical properties of these films in solution containing different alkali metal cations have also been studied. It is anticipated that the presence of crown ether moiety in the film will significantly influence the ion transport within the film. Therefore, the process of doping/undoping of the film during polymer reduction and re-oxidation has been systematically investigated. Such study is of paramount importance from the point of seeking further applications especially in the development of electrochemical redox switches and sensors.

\section{Experimental}

Palladium acetate (Aldrich), $\mathrm{Pd}(\mathrm{ac})_{2}$, and $\mathrm{C}_{60}$ (SES, Houston, TX or Southern Chemical Group) were used as received.
The supporting electrolytes, tetra( $n$-butyl)ammonium perchlorate, $\left(n-\mathrm{Bt}_{4} \mathrm{~N}\right) \mathrm{ClO}_{4}$, lithium perchlorate, $\mathrm{LiClO}_{4}$, lithium hexafluoroarsenate, $\mathrm{LiAsF}_{6}$, lithium tetrafluoroborate, $\mathrm{LiBF}_{4}$, potassium hexafluorophosphate, $\mathrm{KPF}_{6}$, and cesium hexafluoroarsenate, $\mathrm{CsAsF}_{6}$ (Sigma Chemical Co.), were used as received. Acetonitrile (99.9\%) and toluene (99.9\%) were used as received from Aldrich Chemical Co.

Synthesis of 2-(benzo-15-crown-5)fulleropyrrolidine, 1 To $100 \mathrm{ml}$ of dry toluene, $\mathrm{C}_{60}(100 \mathrm{mg}, 0.138 \mathrm{mmol}), 5$ eq. of 4'formylbenzo-15-crown-5 (205 $\mathrm{mg}, 0.694 \mathrm{mmol})$ [45], and 3 eq. of sarcosine ( $37 \mathrm{mg}, 0.416 \mathrm{mmol})$ were added, and the mixture was refluxed for 4-5 h. Solvent was removed under vacuum, and the crude compound was adsorbed onto silica gel and was purified on a silica gel column using toluene and ethyl acetate $(90: 10 v / v)$ as eluent, yielding $\sim 30 \%$. Electrospray ionuzation (EIS) mass in $\mathrm{CH}_{2} \mathrm{Cl}_{2}$ matrix was calculated as 1043.3; found, 1044; the ${ }^{1} \mathrm{H}$ NMR (300 MHz, $\mathrm{CDCl}_{3}$; in ppm), $\delta 7.44(\mathrm{~s}, 1 \mathrm{H}$, phenyl $\mathrm{H}), 7.12(\mathrm{~d}, 1 \mathrm{H}$, phenyl $\mathrm{H})$, $6.90(\mathrm{~d}, 1 \mathrm{H}$, phenyl H), 4.95 (d, 1H, -CH- fulleropyrrolidine ring), $4.84(\mathrm{~s}, 1 \mathrm{H},-\mathrm{CH}$ - fulleropyrrolidine ring), 4.27 (d, $1 \mathrm{H}$, - $\mathrm{CH}$ - fulleropyrrolidine ring), $3.75-4.30(\mathrm{~m}, 16 \mathrm{H}$, crown $-\mathrm{CH}_{2}$-), and $2.81\left(\mathrm{~s}, 3 \mathrm{H}, \mathrm{N}-\mathrm{CH}_{3}\right)$.

Synthesis of 2-(benzo-18-crown-6)fulleropyrrolidine, $2100 \mathrm{mg}$ of $\mathrm{C}_{60}(0.138 \mathrm{mmol}), 5$ eq. of 4'-formylbenzo18-crown-6 [45] (235 mg, $0.694 \mathrm{mmol})$, and 3 eq. of sarcosine $(37 \mathrm{mg}, 0.416 \mathrm{mmol}$ ) were added to $100 \mathrm{ml}$ of toluene, and the mixture was refluxed for $4 \mathrm{~h}$. Solvent was removed under vacuum, and the crude compound was adsorbed onto silica gel and was purified on a silica gel column using toluene and ethyl acetate $(85: 15 v / v)$ as eluent, yielding $\sim 30 \%$. ESI mass in $\mathrm{CH}_{2} \mathrm{Cl}_{2}$ matrix was calculated as 1087.47; found, 1088; the ${ }^{1} \mathrm{H}$ NMR (300 $\mathrm{MHz}, \mathrm{CDCl}_{3}$; in ppm), $\delta 7.41(\mathrm{~s}, 1 \mathrm{H}$, phenyl $\mathrm{H}$ ), $7.14(\mathrm{~d}, 1 \mathrm{H}$, phenyl $\mathrm{H}), 6.90(\mathrm{~d}, 1 \mathrm{H}$, phenyl H), $4.98(\mathrm{~d}$, $1 \mathrm{H},-\mathrm{CH}-$ fulleropyrrolidine ring $), 4.87(\mathrm{~s}, 1 \mathrm{H},-\mathrm{CH}-$
Scheme 1 Structures of 2(benzo-15-crown-5)fulleropyrrolidine, 1 and 2-(benzo-18-crown6)fulleropyrrolidine, 2 used to form two-component films with $\mathrm{Pd}$ in the present study

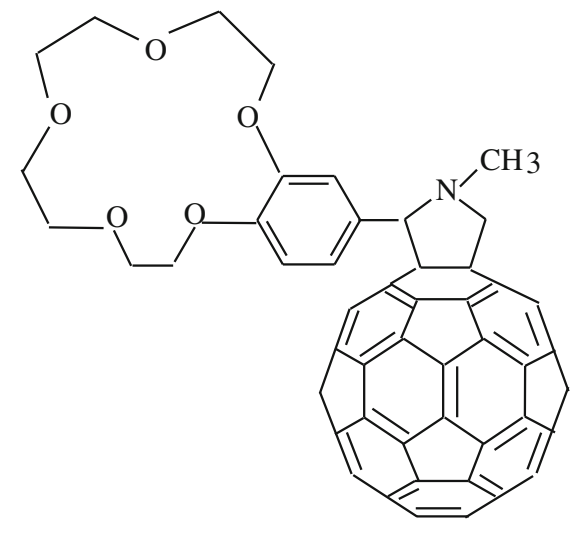

(1)

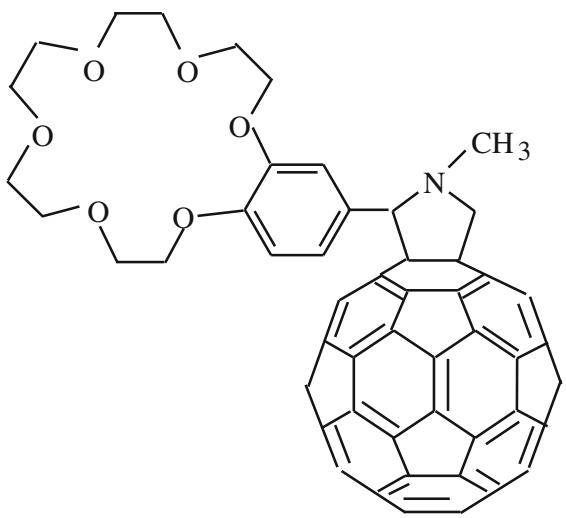

(2) 
fulleropyrrolidine ring), 4.28 (d, $1 \mathrm{H},-\mathrm{CH}$ - fulleropyrrolidine ring), 4.25-3.62 (m, $20 \mathrm{H}$, crown $\left.-\mathrm{CH}_{2}-\right)$, and $2.83(\mathrm{~s}, 3 \mathrm{H}$, $\left.\mathrm{N}-\mathrm{CH}_{3}\right)$.

Voltammetric experiments were performed on a potentiostat/galvanostat Model 283 (EG\&G Instruments) with a threeelectrode cell. A gold disk with a diameter of $1.5 \mathrm{~mm}$ (Bioanalytical Systems, Inc.) was used as the working electrode. Prior to the experiment, the electrode was polished with fine carborundum paper and then with a $0.5-\mu \mathrm{m}$ alumina slurry. Subsequently, the electrode was sonicated in water to remove traces of alumina from the gold surface, washed with water, and dried. The reference electrode was made as follows: a silver wire was immersed in $0.010 \mathrm{M}$ silver perchlorate and $0.09 \mathrm{M}$ tetra( $n$-butyl)ammonium perchlorate in acetonitrile. The reference electrode was separated from the working electrode by a ceramic tip (Bioanalytical Systems Inc.). The counter electrode was a platinum tab with an area of about $0.5 \mathrm{~cm}^{2}$.

Simultaneous voltammetric and piezoelectric microgravimetry experiments were carried out with a home-built potentiostat and an electrochemical quartz crystal microbalance, EQCM 5510 (Institute of Physical Chemistry, Warsaw, Poland). Plano-convex quartz crystals were used. The 14-mm diameter AT-cut, plano-convex quartz crystals with a $5-\mathrm{MHz}$ resonant frequency were obtained from Omig (Warsaw, Poland). A 100-nm gold film, which was vacuum-deposited on the quartz crystal, served as the working electrode. The projected region of this Au electrode was $5 \mathrm{~mm}$ in diameter. The area of the circuit center spot and two contacting radial strips was $0.24 \mathrm{~cm}^{2}$. Unpolished quartz crystals were used for better adherence of the film. The sensitivity of the mass measurement calculated from the Saurbrey equation was $17.7 \mathrm{ng} \mathrm{Hz}^{-1} \mathrm{~cm}^{-2}$.

The studied films were imaged by secondary electron with the use of the S-3000 N scanning electron microscope of Hitachi (Tokyo, Japan). The accelerating voltage of the electron beam was either 10 or $20 \mathrm{keV}$, and the average working distance was $5 \mathrm{~mm}$.

Electrosynthesis of benzo-15-crown-5- $C_{60} / P d$ or benzo-18crown-6- $C_{60} / P d$ films Two-component films of palladium and $\mathrm{C}_{60}$ derivatives of crown ethers were synthesized by electrochemical reduction in acetonitrile/toluene $(1: 4, v / v)$ solutions containing fullerene derivative, palladium acetate, and tetra(n-butyl)ammonium perchlorate as the supporting electrolyte. Films were grown under cyclic voltammetry conditions at a potential sweep rate of $100 \mathrm{mV} / \mathrm{s}$. The amount of material deposited on the electrode surface was obtained using EQCM. Under typical conditions (20 voltammetric cycles), about $55 \mu \mathrm{g} / \mathrm{cm}^{2}$ of both polymers were deposited on the electrode surface. Assuming that the polymer forms a three-dimensional structure proposed by Nagashima and co-workers [46], the mass of monolayer of formed films is equal to 0.148 and $0.155 \mu \mathrm{g} / \mathrm{cm}^{2}$ for benzo- 15-crown-5- $\mathrm{C}_{60} / \mathrm{Pd}$ and benzo-18-crown-6- $\mathrm{C}_{60} / \mathrm{Pd}$, respectively. The size of polymeric monolayer is about $1.8 \mathrm{~nm}$ [34]; the thickness of both films of about $350 \mathrm{~nm}$ was estimated for studied films. The electrochemical properties of the film were studied in an acetonitrile solution containing only the supporting electrolyte. In this case, the electrode covered with the film was removed from the growth solution, rinsed several times with an acetonitrile/toluene $(1: 4, v / v)$ and then placed in an acetonitrile solution containing supporting electrolyte. The modified electrode was allowed to equilibrate for $10 \mathrm{~min}$ while degassing with argon in a fresh solution before electrochemical measurements were performed.

\section{Results and discussion}

Two-component films of palladium and benzo-15-crown-5$\mathrm{C}_{60} / \mathrm{Pd}$ or benzo-18-crown-6- $\mathrm{C}_{60} / \mathrm{Pd}$ were synthesized by electrochemical reduction in acetonitrile/toluene $(1: 4, v / v)$ solutions containing fullerene derivative, palladium acetate, and $\left(n-\mathrm{Bt}_{4} \mathrm{~N}\right) \mathrm{ClO}_{4}$ as the supporting electrolyte. Cyclic voltammograms of the crown ether- $\mathrm{C}_{60} / \mathrm{Pd}$ formation are shown in Fig. 1. The current observed at negative potentials during the negative potentials going scan is related to the process of palladium(II) and $\mathrm{C}_{60}$ moiety reduction [32-34]. Upon repeated scanning of the potential between -200 and $-1,300 \mathrm{mV}$, an increase of current in the potential range of fullerene cage reduction is observed. During potential scanning, a new electrochemically active phase grew on the electrode surface. Also, a shift of reduction potential toward more negative values is observed with the increase of scan number. This shift of reduction potential indicates that the polymeric phase grown on the electrode surface inhibits the process of palladium(II) and fullerene reduction. Similar behavior was observed for electrodeposition of films of palladium and other derivatives of fullerenes [37-39].

The morphology of both films is shown in Fig. 2. Both films grow to a uniform thickness. They are relatively flat with a few outcroppings. The morphology of benzo-15crown-5- $\mathrm{C}_{60} / \mathrm{Pd}$ and benzo-18-crown-6- $\mathrm{C}_{60} / \mathrm{Pd}$ films is similar to the one observed for $\mathrm{C}_{60} / \mathrm{Pd}$ film $[32,36]$. However, films of crown ether derivatives of $\mathrm{C}_{60}$ are more uniform in comparison to the films formed from pristine $\mathrm{C}_{60}$. For comparison, the morphology of $\mathrm{C}_{60} / \mathrm{Pd}$ film obtained for similar experimental conditions is shown in Fig. 2c.

Gold electrode covered with benzo-15-crown-5- $\mathrm{C}_{60} / \mathrm{Pd}$ and benzo-18-crown-6- $\mathrm{C}_{60} / \mathrm{Pd}$ films was transferred to acetonitrile solution containing only the supporting electrolyte, and cyclic voltammograms were recorded. Relevant data obtained in acetonitrile containing different supporting electrolytes are shown in Fig. 3. Both benzo-15-crown-5- $\mathrm{C}_{60} / \mathrm{Pd}$ and benzo- 


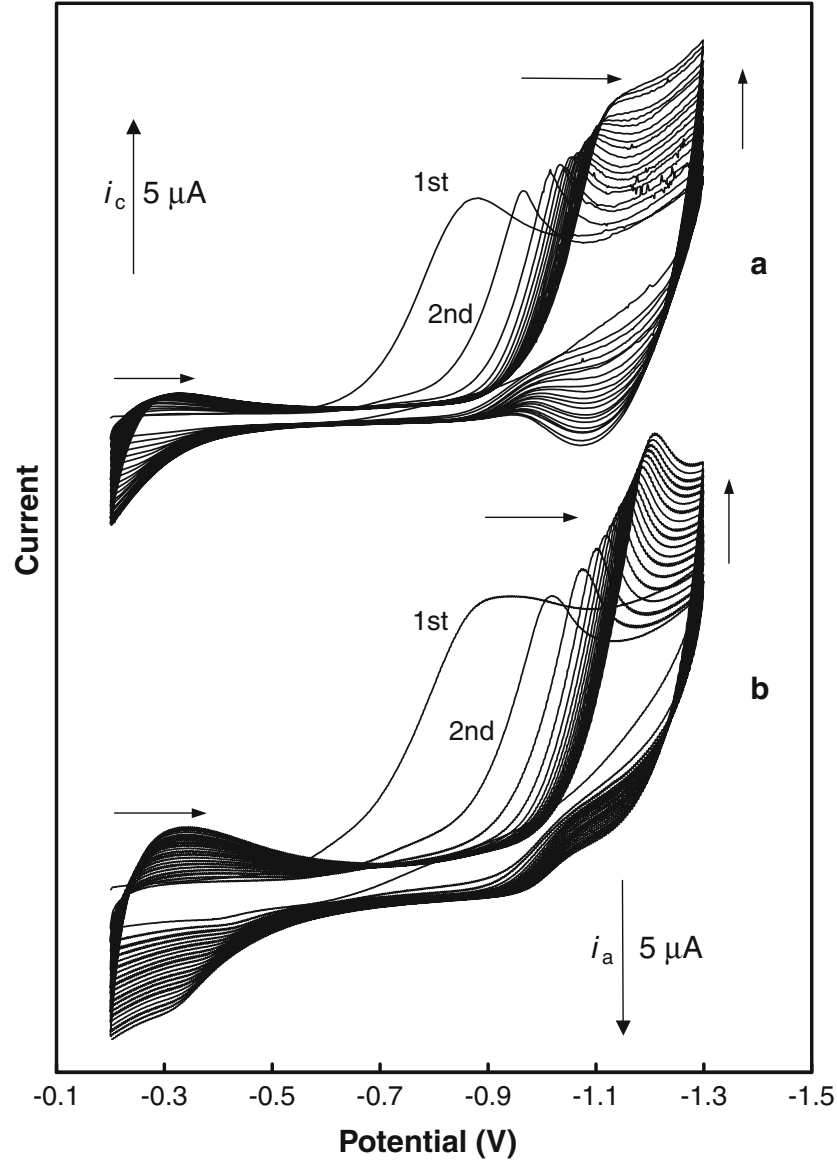

Fig. 1 Multicyclic voltammograms of a benzo-15-crown-5-fulleropyrrolidine/Pd and b benzo-18-crown-6-fulleropyrrolidine/Pd film formation in acetonitrile/toluene $(1: 4, v / v)$ containing $0.1 \mathrm{M}$ tetra $(n-$ butylammonium) perchlorate and a $0.27 \mathrm{mM}$ benzo-15-crown-5fulleropyrrolidine and $3.56 \mathrm{mM} \mathrm{Pd}(\mathrm{ac})_{2}$ and $\mathbf{b} 0.32 \mathrm{mM}$ benzo-18-

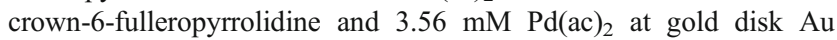
( $1.5 \mathrm{~mm}$ diameter). The sweep rate was $100 \mathrm{mV} / \mathrm{s}$

18-crown- $6-\mathrm{C}_{60} / \mathrm{Pd}$ films are electrochemically active in the negative potential range due to the fullerene moiety reduction process. In the presence of the same supporting electrolyte, voltammetric responses of both films are similar (voltammograms $a$ and $b$ in Fig. 3). The charge transfer processes of the studied films are less reversible in comparison to reduction of $\mathrm{C}_{60} / \mathrm{Pd}$ polymer [32]. In the first reduction step, a sharp reduction peak at about $-900 \mathrm{mV}$ is observed. This peak disappears during the second and subsequent voltammetric cycles. A significant effect of supporting electrolyte cation is observed for the process of film reduction. It may be noted that the potentials of films reduction are less negative in comparison to the potentials of reduction obtained during the process of film formation (Fig. 1). This is mainly due to the different solvents and compositions used in these experiments. Voltammograms presented in Fig. 1 were obtained during films deposition in acetonitrile-toluene containing $\mathrm{Pd}$ $(\mathrm{ac})_{2}$, fullerene derivative and supporting electrolyte. In this case, recorded currents represent three overlapping processes,
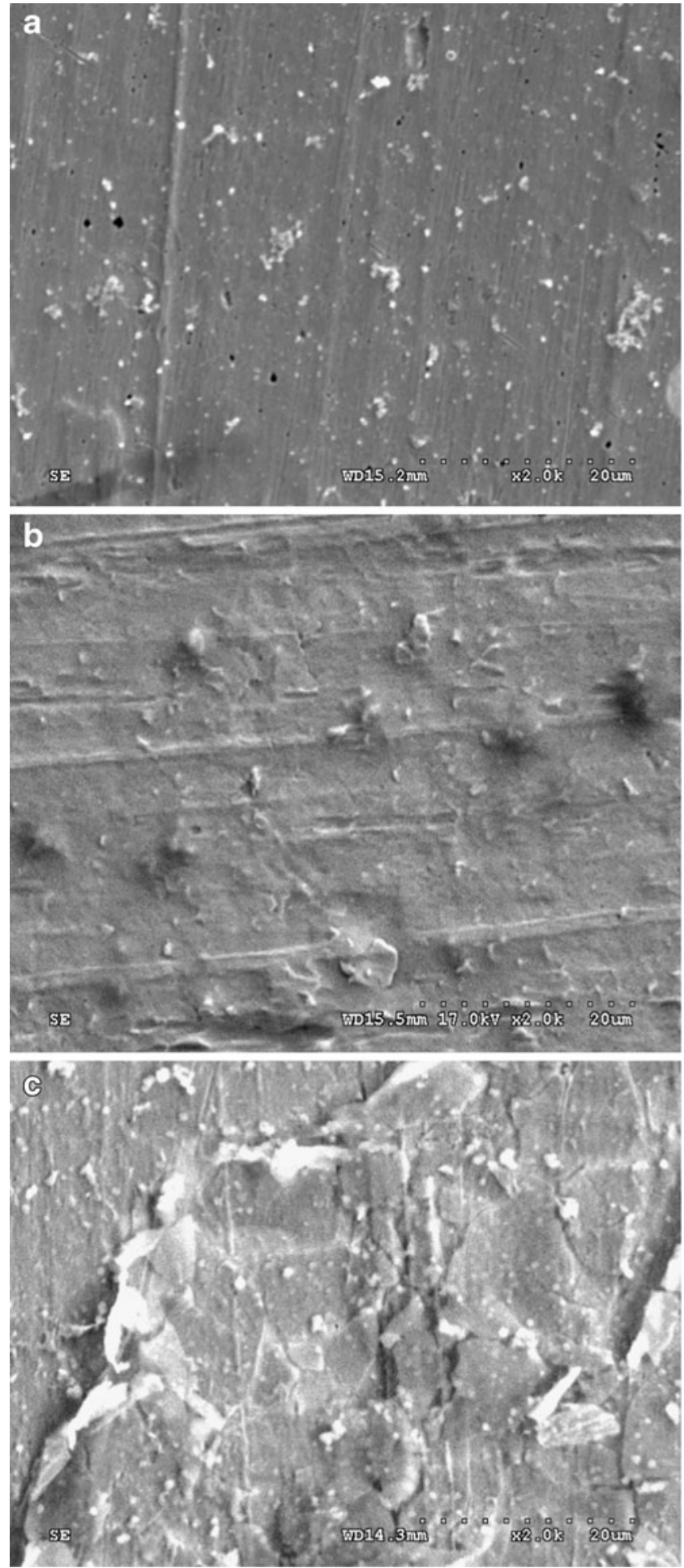

Fig. 2 SEM images of a benzo-15-crown-5-fulleropyrrolidine/Pd, b benzo-18-crown-6-fulleropyrrolidine/Pd, and $\mathbf{c} \mathrm{C}_{60} / \mathrm{Pd}$ films formed on gold foil under cyclic voltammetric conditions after 20 voltammetric cycles in the potential range of 0 to $-1.2 \mathrm{~V}$ in acetonitrile/ toluene $(1: 4, v / v)$ containing $0.10 \mathrm{M}$ tetra( $n$-butyl)ammonium perchlorate. A $3.10 \mathrm{mM} \mathrm{Pd}(\mathrm{ac})_{2}$ and a $0.27 \mathrm{mM} 15$-crown-5- $\mathrm{C}_{60}$, b $0.32 \mathrm{mM}$ 18-crown-6- $\mathrm{C}_{60}$, and c $0.25 \mathrm{mM} \mathrm{C}_{60}$ were employed. The sweep rate was $100 \mathrm{mV} / \mathrm{s}$ 
$\operatorname{Pd}(\mathrm{II})$ reduction, crown ether derivative of $\mathrm{C}_{60}$ reduction, and electrode processes related to reduction of the polymer formed at the electrode surface. Voltammograms presented in Fig. 3 were obtained for polymeric film in acetonitrile solution containing only the supporting electrolyte. Therefore, in this case, voltammetric currents represent only processes related to the film reduction (during negative potentials going scan) and its re-oxidation in the following anodic scan. For the same amount of material deposited at the electrode surface, the charge corresponding to the reduction of benzo-15-crown-5- $\mathrm{C}_{60} / \mathrm{Pd}$ in solution containing alkali metal salts (voltammograms $b$ and $\mathrm{c}$ in Fig. 3) is about 25\% higher than the charge of reduction in solution containing tetra( $n$-alkyl)ammonium perchlorates (voltammogram d in Fig. 3). Such behavior indicates that the amount of material deposited on the electrode surface is being reduced during cathodic voltammetric cycle depends on the permeability of polymeric phase to the counter ions transport.

The process of polymeric layer reduction is accompanied with the transport of the supporting electrolyte ions due to charge balancing. In the case of solutions containing alkali metal cations, the process of reduction of the film can be described by one of the following processes:
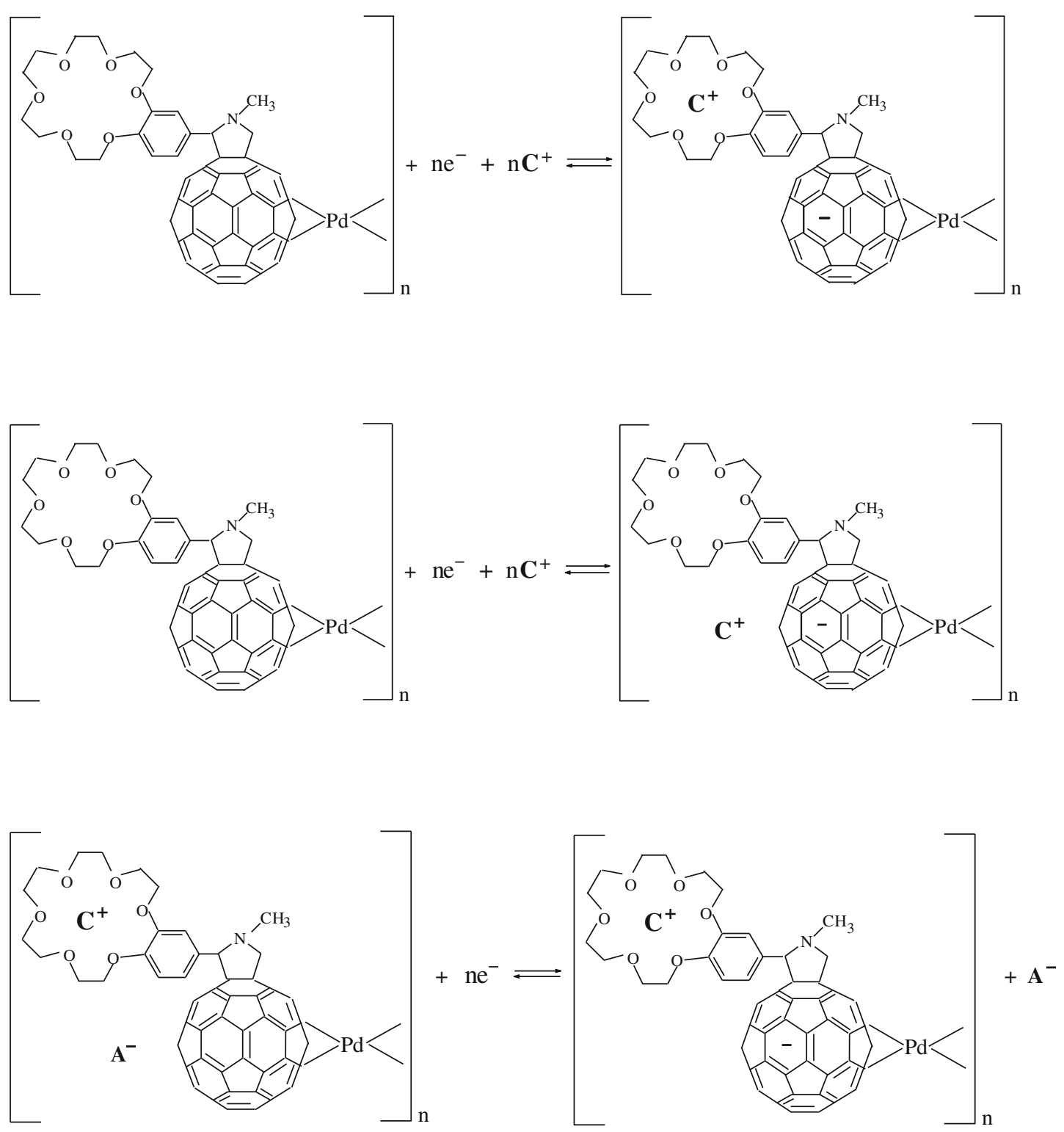


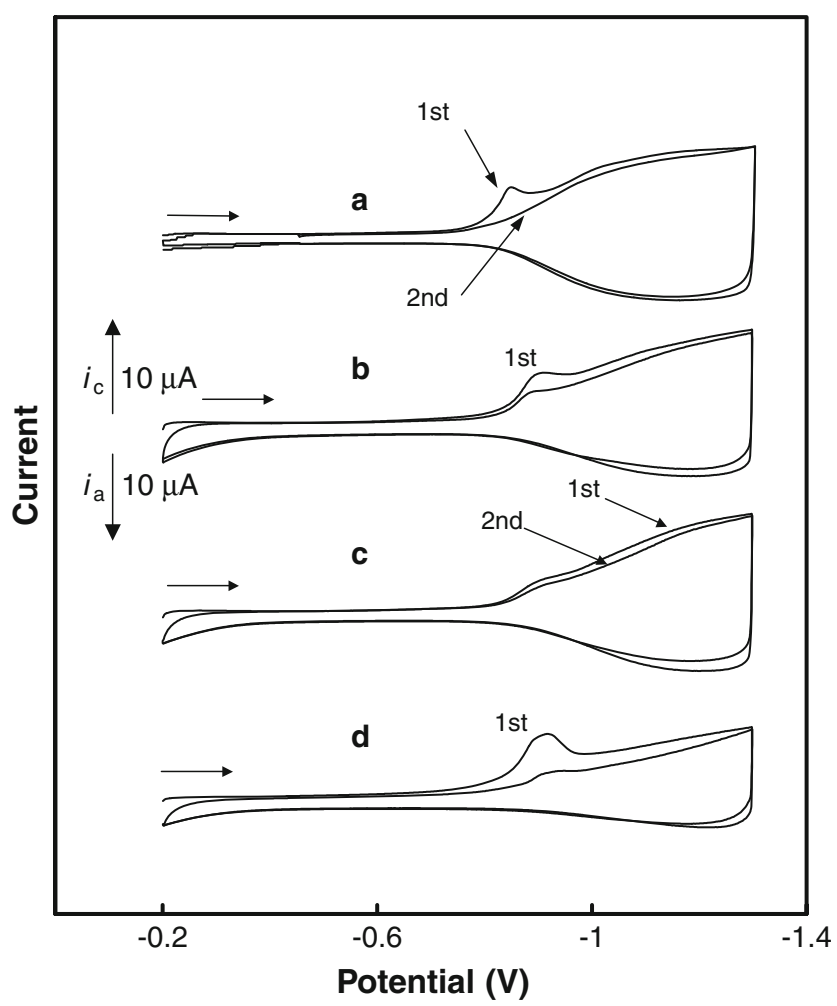

Fig. 3 Cyclic voltammograms of $\mathrm{Au}(1.5 \mathrm{~mm})$ covered with a benzo-15crown-5-fulleropyrrolidine/Pd in acetonitrile containing $0.10 \mathrm{M} \mathrm{LiClO}_{4}$, b benzo-18-crown-6-fulleropyrrolidine/Pd in acetonitrile containing $0.10 \mathrm{M} \mathrm{LiClO}_{4}$, c benzo-18-crown-6-fulleropyrrolidine/Pd in acetonitrile containing $0.10 \mathrm{M} \mathrm{LiBF}_{4}$, and $\mathbf{d}$ benzo-18-crown-6-fulleropyrrolidine/Pd in acetonitrile containing $0.10 \mathrm{M}$ tetra( $n$-butyl)ammonium perchlorate. The sweep rate was $100 \mathrm{mV} / \mathrm{s}$. Films were grown under cyclic voltammetric conditions in acetonitrile/toluene $(1: 4, v / v)$ containing $0.10 \mathrm{M}$ tetra( $n$-butyl)ammonium perchlorate. A $3.10 \mathrm{mM} \mathrm{Pd(ac)})_{2}$ and a $0.27 \mathrm{mM}$ benzo-15-crown-5-fulleropyrrolidine, and (b-d) $0.11 \mathrm{mM}$ benzo-16-crown-6-fulleropyrrolidine were employed

In Eqs. 1 and 2, the cations, $\mathrm{C}^{+}$, move from the bulk electrolyte to the vicinity of the reduced chain site. Cations can be complexated by the crown ether ring (Eq. 1) or can occupy empty spaces in the polymer network (Eq. 2). In the third process (Eq. 3), anions ( $\mathrm{A}^{-}$) which are already present in the film depart from the polymer to the solution.

In order to distinguish between cation and anion transport, electrochemical quartz crystal microbalance studies were performed. In Fig. 4, curves of the changes of resonant frequency, $\Delta f$, vs. potential are presented for benzo-15crown-5- $\mathrm{C}_{60} / \mathrm{Pd}$ film covered electrode in acetonitrile containing $\mathrm{LiClO}_{4}$ (panel a) and tetra( $n$-butyl)ammonium perchlorate (panel b). In acetonitrile solution containing tetra(n-butyl)ammonium perchlorate, decrease of resonant frequency is observed in the potential range of film reduction process. These $\Delta f$ changes are related to the mass changes due to the supporting electrolyte cations incorporation into the film in order to maintain charge neutrality. Such behavior was also observed for $\mathrm{C}_{60} / \mathrm{Pd}$ film [34]. The process of benzo-15-crown-5- $\mathrm{C}_{60} / \mathrm{Pd}$ and benzo-18-crown-6- $\mathrm{C}_{60} / \mathrm{Pd}$
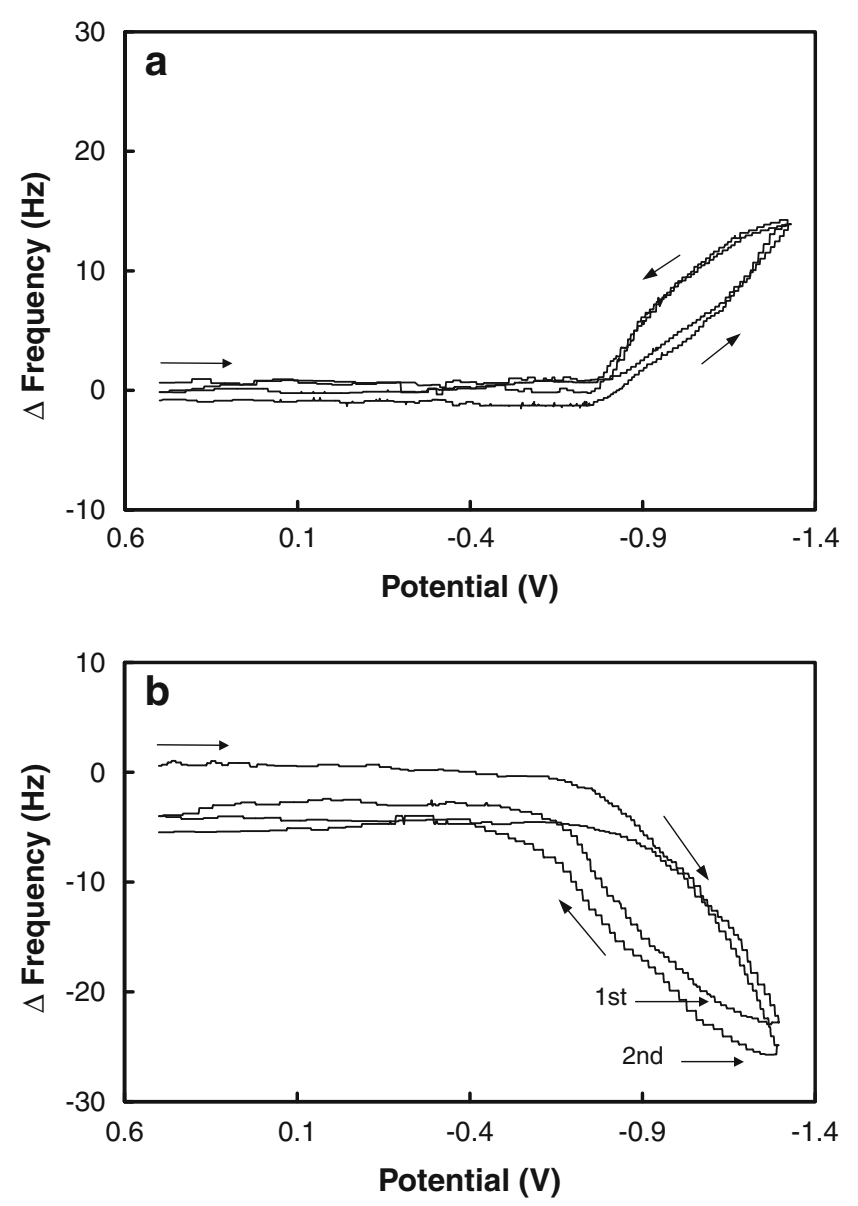

Fig. 4 Curves of the frequency changes vs potential recorded at the $\mathrm{Au}$ /quartz electrode coated with benzo-15-crown-5-fulleropyrrolidine/ Pd film in acetonitrile containing a $0.10 \mathrm{M} \mathrm{LiClO}_{4}$ and $\mathbf{b} 0.10 \mathrm{M}$ tetra (n-butyl)ammonium perchlorate. The sweep rate was $20 \mathrm{mV} / \mathrm{s}$. The benzo-15-crown-5-fulleropyrrolidine/Pd films were grown under cyclic voltammetric conditions in acetonitrile/toluene $(1: 4, v / v)$ containing $0.10 \mathrm{M}$ tetra( $n$-butyl)ammonium perchlorate, $0.27 \mathrm{mM}$ 15-crown-5-fulleropyrrolidine, and $3.10 \mathrm{mM} \mathrm{Pd(ac)})_{2}$

films reduction in presence of large tetra( $n$-alkyl)ammonium cations can be described by cation-involved charge transfer process (Eq. 2). A completely opposite effect is recorded for solution containing $\mathrm{LiClO}_{4}$. In this case, increase of resonant frequency is observed in the potential range of film reduction indicating a decrease of mass at the electrode surface. Such behavior is related to the undoping of the ions from the film. Therefore, the process of film reduction can be described by anion-involved charge transfer process (Eq. 3). The potential ranges of frequency changes correlate very well with the current changes related to the films electroreduction (Fig. 3). A small shift in potentials of voltammetric and frequency responses during films reduction is related to the higher uncompensated IR effect on large electrode used in EQCM measurements.

From the values of frequency changes and the mass of incorporated supporting electrolyte ions, the ratio of the 
charge related to the polymer reduction process in solution containing different supporting electrolytes can be calculated. Results presented in Fig. 4 indicate that the charge of benzo-15-crown-5- $\mathrm{C}_{60} / \mathrm{Pd}$ in $\mathrm{LiClO}_{4}$ is about $29 \%$ higher in comparison to the charge corresponding to the same film reduction in acetonitrile containing tetra( $n$-butyl)ammonium perchlorate. This value agrees well with results obtained on the base of voltammograms (Fig. 3) integration.

After changing of direction of potential scan, frequency increases (in the case of tetra( $n$-butyl)ammonium perchlorate) or decreases (for $\mathrm{LiClO}_{4}$ containing acetonitrile solution) to a value lower than the initial frequency on the beginning of the initial cathodic scan. Differences between initial frequency in the first and second voltammetric cycle are higher for solution containing tetra( $n$-butyl)ammonium perchlorate. Presumably, this is due to the structural changes associated within the film during electroreduction. Such behavior was observed during charging/discharging processes of other conducting polymers [47-49]. A process of irreversible solvent swelling during cathodic cycle can be also responsible for observed differences in starting and final frequency. A slow decomposition of material deposited on the electrode surface due to the counter ions incorporation is also possible. A size of doping ions should be an important parameter in this case.

Voltammetric responses of studied films in acetonitrile solution containing only supporting electrolyte depends on the conditions of film formation and particularly on the concentration of polymerization precursors in the grown solution. Figure 5 shows the effect of ratio of palladium acetate concentration to the concentration of crown ether derivative of $\mathrm{C}_{60},[\mathrm{Pd}] /\left[\right.$ crown $\left.-\mathrm{C}_{60}\right]$ in the grown solution, on the electrochemical properties of benzo-15-crown-5- $\mathrm{C}_{60} / \mathrm{Pd}$ film in acetonitrile containing $\mathrm{LiClO}_{4}$. All voltammograms were obtained for the same mass of polymeric material deposited at the electrode surface. The amount of deposited material was calculated from calibration curves obtained by EQCM. The increase of palladium acetate in grown solution results in decrease of charge of film reduction. Films formed in solution containing large excess of palladium acetate exhibit less reversibility (voltammogram $\mathrm{c}$ in Fig. 5). In the negative potential range, current related to reduction of fullerene moieties is observed. Initially, reduction of fullerene cage results in the formation of sharp reduction peak $R_{1}$ at potential of about $-900 \mathrm{mV}$. This peak is probably related to the reduction of surface layer of benzo-15-crown-5- $\mathrm{C}_{60} / \mathrm{Pd}$ film having direct contact with solution of electrolyte. At more negative potentials, reduction current slowly increases. These current changes are related to the reduction of benzo15-crown-5- $\mathrm{C}_{60} / \mathrm{Pd}$ material buried deeply in the film. In positively going potential sweep, partial re-oxidation of the film is observed at negative potentials, peak $\mathrm{O}_{1}$. The charge of oxidation at negative potentials is substantially lower compared with the reduction charge. A ratio of $\mathrm{Q}_{\mathrm{Ox}} / \mathrm{Q}_{\mathrm{Red}}$ of

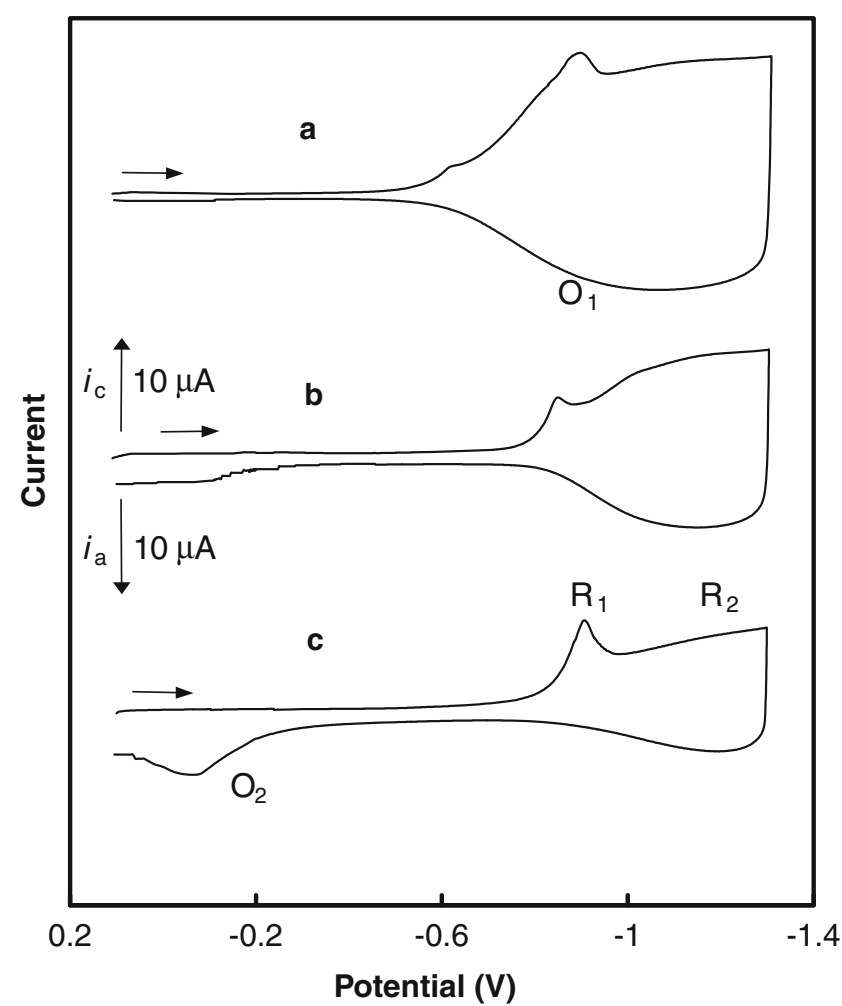

Fig. 5 Cyclic voltammograms of $\mathrm{Au}(1.5 \mathrm{~mm})$ covered with benzo-15crown-5-fulleropyrrolidine/Pd in acetonitrile containing $0.10 \mathrm{M} \mathrm{LiClO}_{4}$. The sweep rate was $100 \mathrm{mV} / \mathrm{s}$. The benzo-15-crown-5-fulleropyrrolidine/Pd films were grown under cyclic voltammetric conditions in acetonitrile/toluene $(1: 4, v / v)$ containing $0.10 \mathrm{M}$ tetra( $n$-butyl)ammonium perchlorate. A $3.10 \mathrm{mM} \mathrm{Pd}(\mathrm{ac})_{2}$ and a $0.33 \mathrm{mM}$ benzo-15-crown-5fulleropyrrolidine, b $0.28 \mathrm{mM}$ benzo-15-crown-5-fulleropyrrolidine, and c $0.11 \mathrm{mM}$ 15-crown-5-fulleropyrrolidine were employed

0.65 was found. Additional slow oxidation of the film is observed at less negative potentials (peak $\mathrm{O}_{2}$ ).

Films formed in solution containing $[\mathrm{Pd}] /\left[\right.$ crown- $\left.\mathrm{C}_{60}\right]$ ratio lower than 15:1 show much higher reversibility of fullerene moieties reduction in the negative potential range (voltammogram b in Fig. 5). In this case, the $\mathrm{Q}_{\mathrm{Ox}} / \mathrm{Q}_{\mathrm{Red}}$ ratio is close to 1 . The effect of grown solution composition on the benzo15-crown-5- $\mathrm{C}_{60} / \mathrm{Pd}$ film electrochemical properties are similar to that observed earlier for $\mathrm{C}_{60} / \mathrm{Pd}$ film [50]. In solutions of high concentration of $\mathrm{Pd}(\mathrm{ac})_{2}$, simultaneous deposition of polymer and metallic particles of palladium take place. Films containing metallic palladium are relatively smooth and exhibit low porosity. The compact and non-porous structure of these films limits the rate of counter-ion transport during the film reduction. In this case, irreversible voltammetric behavior is observed in solution containing only the supporting electrolyte. Films formed in solution containing low concentration of palladium acetate are much more porous. The structure of these films allows for solvent wetting and for penetration of the film with ions of supporting electrolyte. In these systems, reversible charge transfer process is observed (Fig. 5a). 


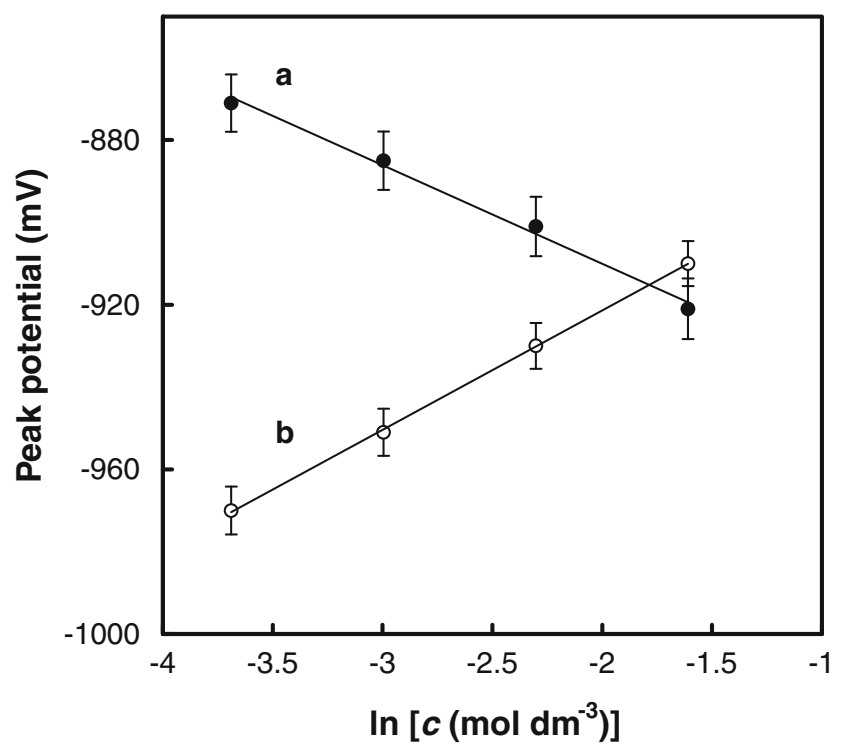

Fig. 6 Plot of peak potential of benzo-18-crown-6-fulleropyrrolidine/ $\mathrm{Pd}$ film electroreduction versus $\mathbf{a} \mathrm{KPF}_{6}$ and $\mathbf{b}$ teta( $n$-butyl)ammonium perchlorate concentration in acetonitrile. Sweep rate was $100 \mathrm{mV} / \mathrm{s}$. The benzo-18-crown-6-fulleropyrrolidine/Pd film was grown under cyclic voltammetric conditions in acetonitrile/toluene $(1: 4, v / v)$ containing $0.10 \mathrm{M}$ tetra( $n$-butyl)ammonium perchlorate, $0.30 \mathrm{mM}$ benzo-18-crown-6-fulleropyrrolidine, and $3.10 \mathrm{mM} \mathrm{Pd(ac})_{2}$

Relations of peak potential on the $\ln c$ obtained for the process of benzo-18-crown-6- $\mathrm{C}_{60} / \mathrm{Pd}$ film reduction in acetonitrile containing different concentration of $\mathrm{KPF}_{6}$ and tetra( $n$-butyl)ammonium perchlorate are shown in Fig. 6. Assuming that the charge transfer process of the film reduction is reversible and described by the Nernst equation, the formal potential for the film reduction process on the supporting electrolyte concentration is expressed by the following equation [51]:

$$
\begin{aligned}
E_{\mathrm{f}}= & E_{\mathrm{f}}^{0}+\frac{R T}{n F} \ln \frac{\left[\mathrm{C}^{+} @ \text { Crown }-\mathrm{C}_{60} / \mathrm{Pd}\left(\mathrm{A}^{-}\right)_{\mathrm{m}}\right]}{\left[\mathrm{C}^{+} @ \text { Crown }-\mathrm{C}_{60}^{\mathrm{n}-} / \operatorname{Pd}\left(\mathrm{A}^{-}\right)_{\mathrm{m}-\mathrm{n}}\right]} \\
& -\frac{R T}{F} \ln \left[\mathrm{A}^{-}\right]
\end{aligned}
$$

$$
\begin{aligned}
E_{\mathrm{f}}= & E_{\mathrm{f}}^{0}+\frac{R T}{n F} \ln \frac{\left[\text { Crown }-\mathrm{C}_{60} / \mathrm{Pd}_{\mathrm{m}}\right]}{\left[\text { Crown }-\mathrm{C}_{60}^{\mathrm{n}-} / \mathrm{Pd}\left(\mathrm{C}^{+}\right)_{\mathrm{m}-\mathrm{n}}\right]}+\frac{R T}{F} \\
& \times \ln \left[\mathrm{C}^{+}\right]
\end{aligned}
$$

Here, Eq. 4 represents potential changes of the process described by reaction (3). The process that involves doping of the layer with cations of supporting electrolyte, reaction (1) and (2), is described by Eq. 5. Equation 4 predicts a negative shift of formal potential with increase of anion concentration in the solution. Such behavior is observed for the process of film reduction in solution containing $\mathrm{KPF}_{6}$. A good linear $E_{\mathrm{p}}-\ln c$ with a slope of

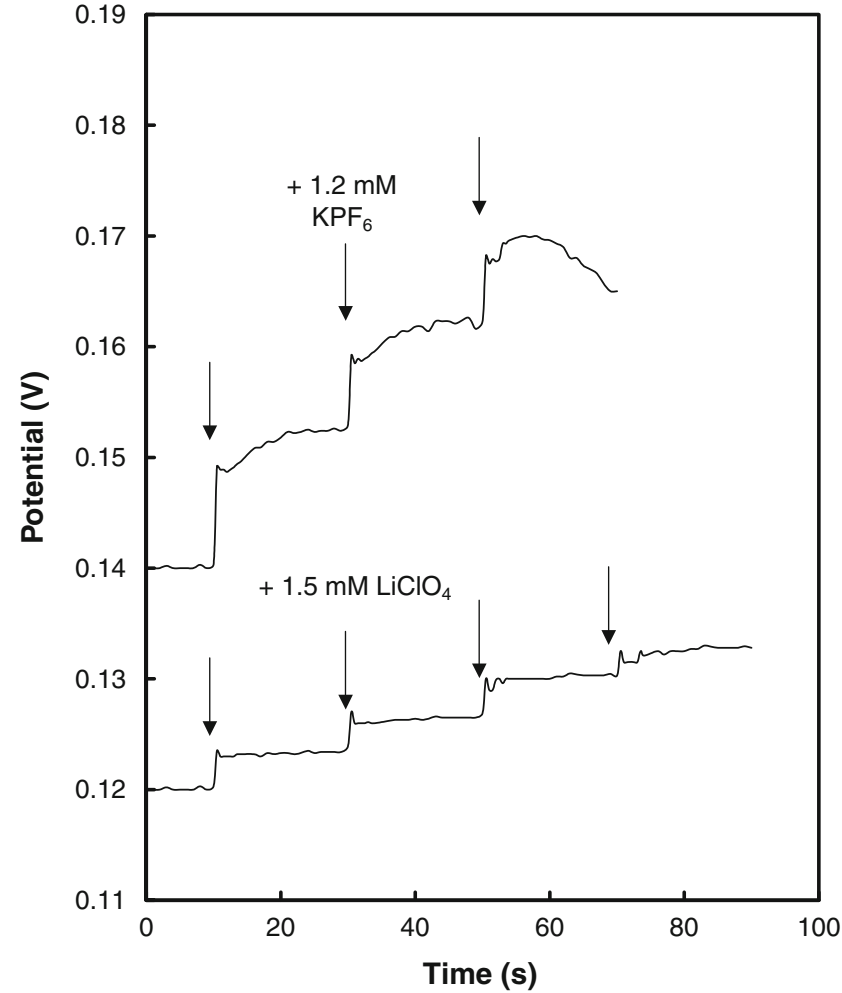

Fig. 7 Changes of potential of gold electrode (1.5 mm diameter) covered with the benzo-18-crown-6-fulleropyrrolidine/Pd film immersed in acetonitrile containing $0.1 \mathrm{M}$ tetra(n-butyl)ammonium perchlorate during addition of solution containing either $\mathrm{LiClO}_{4}$ or $\mathrm{KPF}_{6}$. The benzo-18-crown-6-fulleropyrrolidine/Pd film was grown under cyclic voltammetric conditions in acetonitrile/toluene $(1: 4, v / v)$ containing $0.10 \mathrm{M}$ tetra( $n$-butyl)ammonium perchlorate, $0.30 \mathrm{mM}$ benzo-18-crown-6-fulleropyrrolidine, and $3.10 \mathrm{mM} \mathrm{Pd(ac)})_{2}$

$24 \mathrm{mV} / \mathrm{ln}$ unit is observed. The value of this slope is very close to the one predicted by Eq. 4 which is equal to $25 \mathrm{mV} / \mathrm{ln}$ unit at $20{ }^{\circ} \mathrm{C}$. The above results also indicate that the process of polymer reduction in solution containing alkali metal cations is described by reaction (3), and alkali metal cations are bound by crown ether cavity. A positive shift of reduction potential is observed for solution containing tetra( $n$-butyl)ammonium perchlorate. A slope of linear relation between $E_{\mathrm{p}}$ and $\ln c$ is equal to $29 \mathrm{mV}$ per ln unit. This value is slightly higher that the theoretically predicted slope due to partially uncompensated solution resistance. Results obtained for solution containing tetra( $n$-butyl)ammonium perchlorate indicate that cations of supporting electrolyte are involved in the process of film reduction in solution containing tetra $(n$ alkyl)ammonium salts according to reaction (2).

The above presented results indicate that benzo-15-crown5- $\mathrm{C}_{60} / \mathrm{Pd}$ and benzo-18-crown-6- $\mathrm{C}_{60} / \mathrm{Pd}$ films coordinate alkali metal cations from the solution by crown ether moiety. The formation constant of crown ether complexes of alkali metal cations depends on the size of metal ion and the size of 
crown ether cavity. Therefore, a selective complexation of alkali metal cations can be expected for studied polymers. The primary study of the selective bonding of alkali metal ions were done for electrodes covered with benzo-18-crown-6- $\mathrm{C}_{60} /$ $\mathrm{Pd}$ film. The modified electrode was immersed in acetonitrile solution containing tetra( $n$-butylammonium) perchlorate as supporting electrolyte. After potential equlibration, a constant portion of solution containing either $\mathrm{LiClO}_{4}$ or $\mathrm{KPF}_{6}$ were added. Figure 7 shows the changes of the potential of the electrode modified with benzo-18-crown-6- $\mathrm{C}_{60} / \mathrm{Pd}$ after addition of solution containing either $\mathrm{K}^{+}$or $\mathrm{Li}^{+}$ions. The shift of electrode potential in the presence of alkali metal cations is observed. For the same concentration of added cation, potential changes are higher for $\mathrm{K}^{+}$in comparison to $\mathrm{Li}^{+}$ions. The trend in potential changes agrees with differences in the formation constant of benzo-18-crown-6 complexes of $\mathrm{Li}^{+}$and $\mathrm{K}^{+}$. For benzo-18-crown- 6 complexes, formation constant, $K$, is in order $\mathrm{Li}^{+}<\mathrm{Na}^{+}<\mathrm{K}^{+}>$ $\mathrm{Cs}^{+}[22]$.

\section{Conclusions}

Crown ether-bearing fulleropyrrolidine derivatives can be electrochemically introduced into the polymeric network through palladium atoms coordinated directly to the fullerene cage in $\eta^{2}$ fashion. These systems exhibit electrochemical activity in the negative potentials range due to the $\mathrm{C}_{60}$ moiety reduction. In solution containing large tetra(alkyl)ammonium cations, the polymer reduction process is accompanied by the transport of tetra(alkyl) ammonium cations from the solution to the polymeric phase. In the presence of alkali metal cations in solution, the cations are coordinated to the crown ether moiety. In order to balance positive charges, the film is simultaneously doped with anions of supporting electrolyte. During the film reduction, these anions are transported from the polymeric phase to the solution. Therefore, the doping process can be tuned by changing solution composition. Polymers based on crown ether-bearing fulleropyrrolidine can also selectively coordinate alkali metal cations depending on the size of crown ether cavity and cation radius.

Acknowledgments Financial support from the Polish Ministry of Science and Higher Education (project no. N 204374733 to KW) and National Science Foundation (Grant 0804015 to FD) is gratefully acknowledged.

Open Access This article is distributed under the terms of the Creative Commons Attribution Noncommercial License which permits any noncommercial use, distribution, and reproduction in any medium, provided the original author(s) and source are credited.

\section{References}

1. Prato M, Maggini M (1998) Acc Chem Res 31:519

2. Maggini M, Scorrano G, Prato M (1993) J Am Chem Soc 115:9798

3. Herrans MA, Illescas B, Martin N, Luo C, Guldi DM (2000) J Org Chem 65:5728

4. Herrans MA, Martin N, Sanchez L, Seoane C, Guldi DM (2000) J Organomet Chem 599:2

5. Guldi D, Maggini M, Scorrano G, Prato M (1997) J Am Chem Soc 119:974

6. Matsumoto K, Ciobanu M, Katsura H, Ohta R, Uchida T (1996) Heterocycl Commun 2:545

7. Liddle P, Kuciauskas D, Sumida JP, Nash B, Nguyen D, Moore TA, Gust D (1997) J Am Chem Soc 119:1400

8. Wilson SR, Wang YH, Cao JR, Tan XF (1996) Tetrahedron Lett $37: 775$

9. Zheng DG, Li CW, Li YL (1998) Synth Commun 28:2007

10. Kuciauskas D, Lin S, Seely GR, Moore AL, Moore TA, Gust D, Drovetskaya T, Reed CA, Boyd PDW (1996) J Phys Chem 100:15926

11. Guo ZX, Li YL, Xu JH, Mao Z, Wu Y, Zhu DB (1998) Synth Commun 28:1957

12. Ge Z, Li Y, Shi Z, Bai F, Zhu D (2000) J Phys Chem Solids 61:1075

13. Garlaschelli L, Messina I, Pasini D, Righetti PP (2002) Eur J Org Chem 3385

14. Illescas BM, Santos J, Diaz MC, Martin N, Atienza CM, Guldi DM (2007) Eur J Org Chem 5027

15. Alfimov MV, Fedorov YV, Fedorova OA, Gromov SP, Hester RE, Lednev IK, Moore JN, Oleshko VP, Vedernikov AI (1997) J Chem Soc Perkin Trans 2:1441

16. Alfimov MV, Churokov AV, Fedorov YV, Fedorova OA, Gromov SP, Hester RE, Howard JAK, Kuzmina LG, ILednev IK, Moore JN (1997) J Chem Soc Perkin Trans 2:12249

17. Arias F, Godinez L, Wilson SR, Kaifer AE, Echegoyen L (1996) J Am Chem Soc 118:6086

18. Bourgeois JP, Echegoyen L, Fibbiroli M, Pretsch E, Diederich F (1998) Angew Chem Int Ed 37:2118

19. Van Eis M, Seiler P, Diederich F, Alvarado RJ, Echegoyen L (2000) Chem Commun 1859

20. Van Eis MJ, Perez Nunez I, Muslinkina LA, Alvarado RJ, Pretsch E, Echegoyen L, Diederich F (2001) J Chem Soc Perkin Trans 2:1890

21. Smith PM, McCarty AL, Nguyen NY, Zandler ME, D’Souza F (2003) Chem Commun 1754

22. Izatt RM, Pawlak K, Bradshaw JS, Bruening RL (1991) Chem Rev 91:1721

23. Gokel GW, Leevy WM, Weber ME (2004) Chem Rev 104:2723

24. Steed JW (2001) Coord Chem Rev 215:171

25. Sannicolo F, Brenna E, Benicori Zotti TG, Zecchin S, Schiavon G, Pilati GT (1998) Chem Mater 10:2167

26. Youssoufi HK, Hmyene M, Garnier F, Delabouglise D (1993) J Chem Soc Chem Commun 1550

27. Youssoufi HK, Yassar A, Baiteche S, Hmyene M, Garnier F (1994) Synth Met 67:251

28. Bauerle P, Scheib S (1993) Adv Meter 5:848

29. Marsella MJ, Swager TM (1993) J Am Chem Soc 115:12214

30. Yamamoto T, Omote M, Miyazaky Y, Kashiwazaki A, Lee B, Kanbara T, Osakada K, Inoue T, Kubota K (1997) Macromolecules 30:7158

31. Cadogan A, Gao Z, Lewenstam A, Ivaska A (1992) Anal Chem 64:249626

32. Balch AL, Costa DA, Winkler K (1998) J Am Chem Soc 120:9614 
33. Winkler K, De Bettencourt-Dias A, Balch AL (1999) Chem Mater $11: 2265$

34. Winkler K, Noworyta K, Kutner W, Balch AL (2000) J Electrochem Soc 147:2597

35. Hayashi A, De Bettencourt-Dias A, Winkler K, Balch AL (2002) J Mater Chem 12:211630

36. Grodzka E, Grabowska J, Wysocka-Zolopa M, Winkler K (2008) J Solid State Electrochem 12:126731

37. Plonska ME, De Bettencourt-Dias A, Balch AL, Winkler K (2003) Mater Chem 15:4122

38. Plonska ME, Makar A, Winkler K, Balch AL (2004) Pol J Chem 78:1431

39. Winkler K, Plonska-Brzezinska ME, Gadde S, D’Souza F, Balch AL (2006) Electroanalysis 18:841

40. Pieta P, Grodzka E, Winkler K, Warczak M, Sadkowski A, Zukowska GZ, Venukadasula GM, D’Souza F, Kutner W (2009) J Phys Chem B 113:6682

41. Inzelt G, Bacskai J (1992) Electrochim Acta 37:647
42. Hillman AR, Loveday DC, Bruckenstein S (1989) J Electroanal Chem 274:157

43. Ko JM, Rhee HW, Park SM, Kim CY (1990) J Electrochem Soc 137:905

44. Schroeder SH, Kaufman FB (1980) J Electroanal Chem 113:209

45. Chitta R, Rogers LM, Wanklyn A, Karr PA, Kahol PK, Zandler ME, D’Souza F (2004) Inorg Chem 43:6969

46. Nagashima H, Nakaoka A, Saito Y, Kato M, Kawanishi T, Itoh K (1992) J Chem Soc Chem Commun 377

47. Teh KS, Takahashi Y, Yao Z, Lu YW (2009) Sens Actuators A Phys 155:113

48. Chainet E, Billon M (1999) Synth Met 99:21

49. Brown NMD, You HX, Forster RJ, Vos JG (1990) J Mater Chem $1: 1990$

50. Winkler K, De Bettencourt-Dias A, Balch AL (2000) Chem Mater 12:1386

51. Levi MD, Lopez C, Vieil E, Vorotyntsev MA (1997) Electrochim Acta $42: 757$ 